\title{
A Study on the Financing Effect of U.S. Debt from the Perspective of Modern Monetary Theory-Also on the Innovation Driving Effect of Monetary Sovereignty
}

\author{
Chunyang Cheng ${ }^{1, a^{*}}$ \\ ${ }^{1}$ International Business School of Shaanxi Normal University, Xi'an,Shaanxi,China
}

\begin{abstract}
The traditional view is that China uses the foreign exchange income earned from the trade surplus to purchase U.S. treasury bonds, which provides financing for U.S. government expenditures and maintains the sustainability of U.S. public debt. Based on the modern monetary theory, this paper analyzes this phenomenon and believes that China's trade surplus cannot finance US government expenditures. U.S. debt issuance can exert interest rate stabilization effect, exchange rate stabilization effect, currency issuance effect and innovation "crowding-out" effect, but it has no financing effect. Therefore, this paper puts forward some policy suggestions, such as increasing the central government expenditure and the issuance of treasury bonds, and implementing the reform of floating exchange rate system, in order to increase the monetary sovereignty of our country and give full play to the government's role in promoting domestic economic innovation.
\end{abstract}

\section{Introduction}

In recent years, with the continuous increase of China's trade surplus, China's holdings of U.S. treasury bonds have also been growing. In this regard, the traditional view is that China will trade surplus accumulated foreign exchange income to buy U.S. treasury bonds to finance U.S. fiscal expenditures, which indirectly maintains the sustainability of U.S. public debt. However, some scholars believe that the purpose of the issuance of U.S. treasury bonds is not to finance government expenditures. As Randall Wray, the founder of modern monetary theory, said, "The issuance of government bonds is part of monetary policy, not to finance fiscal deficits. ". This is our understanding of "can China's trade surplus finance U.S. fiscal expenditures?". This issue provides a new theoretical perspective. Therefore, based on the existing research, this paper will summarize the traditional theory's understanding of "U.S. debt financing" and its shortcomings, then interpret the effect of U.S. debt financing from the perspective of modern monetary theory, and finally summarize the whole paper and put forward relevant policy recommendations.

\section{2 literature review}

For a long time, the issuance of government bonds has been regarded as a means used by the central government to make up for the fiscal deficit and maintain the sustainability of public debt. Based on this, it is generally believed that China uses the foreign exchange income earned from the trade surplus to purchase U.S. treasury bonds to finance U.S. government expenditures and maintain the sustainability of U.S. public debt. McKinnon(2005) believes that the US government is actually provided with a free credit line by the US treasury bonds held by foreign central banks, thus indirectly supporting the US fiscal deficit [1]. Dooley et al(2004) believed that emerging markets, represented by China, financed the U.S. by trading the U.S. dollars earned from the trade surplus for U.S. debt, which the U.S. exported to surplus countries through the trade deficit, thus constituting a "dollar circulation". However, some studies also believe that the purpose of US debt issuance is not to finance government expenditures [2]. Bell(2000) found out after analyzing the operation details between the U.S. Treasury Department and the central bank that the purpose of the issuance of U.S. treasury bonds is not to finance U.S. government expenditures, but as a mechanism to maintain interest rates [3]. Jia Genliang (2019) pointed out that besides serving as a mechanism to maintain interest rates, US debt issuance can also play a role as a currency issuance mechanism [4]. Huang Yijiang (2020) further pointed out that the purchase of U.S. debt by U.S. dollars that China will earn not only cannot finance U.S. government expenditures, but also maintains the stability of the U.S. dollar exchange rate. Other studies suggest that the US public debt is sustainable because the US is able to finance its expenditures by continuously borrowing foreign debt [5]. Pan Hongsheng (2010) believes that foreign investors' preference for U.S. treasury bonds has enabled the United States to obtain large amounts of cheap financing

*Corresponding author: a947397281@qq.com 
at low interest rates, thus maintaining the sustainability of U.S. public debt [6]. Maggiori(2018) believes that the US dollar's status as an international currency reduces the US deficit financing constraint, allowing the US to finance its expenditures by borrowing in local currency, thus making US public debt sustainable. However, some scholars believe that US public debt is not sustainable [7]. Li Jing and Yi Nan (2014) believe that the public debt of the United States is unsustainable in three ways: firstly, the economic growth rate of the United States is lower than the public debt level; secondly, the debt level of the United States has exceeded the fiscal targets stipulated in the "Maastricht Treaty"; and finally, there is no cointegration relationship between the fiscal revenue, fiscal expenditure and the proportion of fiscal surplus and the proportion of public debt in the United States [8].

It can be seen that there are different views on whether China's trade surplus is financing US government expenditure and whether US public debt is sustainable. However, it is obviously of great theoretical and practical significance to clarify the above-mentioned issues in order to solve the long-standing U.S. debt problem that has plagued our country. Therefore, this paper will first analyze the fallacies of the traditional theory on the U.S. debt problem, then analyze the effect of U.S. debt from the perspective of modern monetary theory, and finally summarize the full text and put forward relevant policy recommendations.

\section{The traditional analysis of "US debt financing"}

It is generally believed that as a recipient of money, the government's way of obtaining income, i.e,money, is not significantly different from that of households and enterprises. For the private sector, they can finance their spending in three ways. First, monetary income is derived from the sale of goods and services as a source of expenditure. Second, access to finance by borrowing from other non-banking economies. Third, access to capital through bank borrowings. Generally speaking, the first of the three ways to finance expenditures is an important prerequisite for ensuring the sustainability of private sector deficits and debt. Based on this, the traditional theory established the budget constraint equation of government departments:

$$
G+i B^{N o n-G o v t}=T+\Delta B^{N o n-G o v t}+\Delta M
$$

In the above equation, the left side represents government expenditure, including government recurrent expenditure and debt interest expenditure, and the right side represents government revenue, including tax revenue, income from issuing bonds to the private sector, and income from borrowing directly from the central bank through debt monetization. In fact, because the federal reserve act in the United States as early as 1993 clearly stipulated that the Ministry of Finance could not obtain financing directly from the Federal Reserve and the market through debt monetization, the budget constraint equation of government departments can be rewritten as:

$$
G+i B^{N o n-G o v t}=T+\Delta B^{\text {Non-Govt }}
$$

It can be seen that tax revenue and bond issuance constitute the revenue source of a government that abides by fiscal discipline. As the issue of government bonds will not only lead to competition with the private sector for loanable funds, which will push up interest rates and squeeze out private investment, it may also lead to unsustainable public debt. Therefore, in the long run, the government needs to implement fiscal consolidation and reduce public debt. The Maastricht Treaty also takes whether the public debt /GDP exceeds $60 \%$ as the criterion to judge whether the public debt is reasonable. The International Monetary Fund (IMF) and the European Central Bank (ECB) have also defined the sustainability of public debt as follows:

$$
\sum_{i=0}^{\infty} \frac{E_{t+i}}{\prod_{j}^{i}\left(1+r_{t+j}\right)} \leq \sum_{i=0}^{\infty} \frac{Y_{t+i}}{\prod_{j}^{i}\left(1+r_{t+j}\right)}-\left(1+r_{t}\right) \cdot D_{t-1}
$$

The left side of the equation represents the discounted value of future government expenditure, while the right side of the equation represents the discounted value of future income minus debt balance. This means that public debt is considered sustainable only when the present value of government public revenue is enough to make up for the present value of recurrent expenditure and government debt.

Further, to specifically measure the sustainability of public debt, there are three common assessment methods. First, the debt ratio method. This approach considers that government expenditures (including current expenditures and debt interest payments) need to be financed by taxes and borrowing,Public debt is considered sustainable when the interest rate on debt is less than the economic growth rate, and unsustainable if the interest rate is not. Second, the present value budget constraint. The method considers that the current public debt of the government can be made up by continuing to borrow in the future or increasing future fiscal surplus. The condition for the sustainability of government public debt is that the government public debt is no longer financed by "borrowing new to repay the old",Therefore, the government public debt is considered to be sustainable when the discounted value of the indefinite government debt equals zero. This means that government debt can be covered by future fiscal surpluses. Third, the debt threshold method. This approach considers that whether a country's public debt is sustainable or not can also be defined by comparing the size of the country's debt with the "moderate" debt size, or the debt ceiling. First, for different countries, there is an optimal debt scale, When the domestic debt scale is less than this optimal debt scale, the growth of public debt is beneficial to economic growth, which can effectively maintain the sustainability of public debt. However, when the domestic debt scale 
exceeds this optimal debt scale, the growth of public debt will have a negative impact on the economy, which may lead to unsustainable public debt. Secondly, the corresponding debt ceiling is determined for different countries,Public debt above this debt ceiling is considered to be unsustainable, and vice versa.

\section{Analysis of "U.S. Debt Financing" from the Perspective of Modern Monetary Theory: Criticism and Reflection}

In fact, modern monetary theory (MMT) has already addressed the issue of whether the issuance of treasury bonds is financing government expenditures. Modern monetary theory holds that the issuance of government bonds does not finance government expenditures, Its main viewpoints are as follows: (1) Both government bonds and sovereign currencies are debts of sovereign governments, The difference is that the liquidity of government bonds is lower but the yield is higher, On the contrary, sovereign currencies have higher liquidity but lower yield than government bonds. The issue of treasury bonds merely turned illiquid bond swap into more liquid debt, similar to the conversion of bank time deposits into demand deposits. Therefore, the central government does not need to borrow its own debt to finance its expenditures. (2) the government expenditure is the currency issue, that is to say, the central government is to create money to spend, so there is no need to rely on government bonds to finance its expenditures. This is particularly evident in the modern banking monetary system. As shown in table 1, if the U.S. federal government carries out recurrent fiscal expenditure of $\$ 100$, then the commercial banks will correspondingly increase the base currency of $\$ 100$,In this process, the central bank's balance sheet will be debited into the fiscal deposits and credited into the commercial bank reserve at the same time, that is to say, the government expenditure will create currency at the same time.

Table 1.Changes in the Balance Sheet of the Central Bank after Central Fiscal Expenditure

\begin{tabular}{c|c} 
Assets & Liabilities \\
\hline & $\begin{array}{c}-100 \text { dollar Treasury deposits } \\
+100 \text { dollar commercial bank } \\
\text { deposits }\end{array}$
\end{tabular}

It is not difficult to find that although fiscal expenditure will directly lead to the issuance of money, if we further explore where the government's fiscal funds for expenditure come from, we will inevitably draw the conclusion that "it comes from taxation or bond issuance". The reason why we think so is that the "federal reserve act" has already expressly stipulated that "the government cannot finance government expenditures through direct overdraft or through direct subscription and underwriting of government bonds in the primary market". The traditional view is that finance can only be financed from the private sector through taxation or borrowing. However, this is only one side of the
truth,The other side of the truth is that the United States has already bypassed the relevant provisions in the "federal reserve act" that prohibit the central bank from financing fiscal expenditures by way of "national debt issuance+open market operation". Assuming that the Ministry of Finance issues US\$ 100 of treasury bonds before spending, the balance sheet of the central bank after the primary dealer purchases the treasury bonds is shown as follows (Table 2). As the issuance of treasury bonds led to a decrease in reserves in the inter-bank market, the central bank bought $\$ 100$ of treasury bonds in the secondary market through open market operations to ensure the banking system had sufficient reserves. In the process, the reserve of commercial banks increased by US\$ 100 while the balance sheet of the central bank increased by US\$ 100 . It can be seen that the United States has already bypassed the "monetization of debt" provision prohibited by relevant laws through relevant operations, so the U.S. Treasury Department can always make expenditures by creating money without borrowing from the private sector for financing.

Table 2.Changes in the Balance Sheet of the Central Bank after the issuance of treasury bonds by the Ministry of Finance

\begin{tabular}{c|c} 
Assets & Liabilities \\
\hline & +100 dollar Treasury deposits \\
-100 dollar commercial bank \\
deposits
\end{tabular}

Table 3. Balance Sheet Changes after Central Bank Open Market Operation

\begin{tabular}{c|c} 
Assets & Liabilities \\
\hline+ National debt & +100 dollar commercial bank \\
deposits
\end{tabular}

As mentioned earlier, the issuance of U.S. treasury bonds does not finance its expenditures, which means that the "debt crisis that may result from excessive U.S. government debt" feared by the traditional view does not actually happen. Because U.S. government debt is denominated in U.S. dollars, as a supplier of U.S. dollars, the U.S. federal government can always pay its own debt by creating money without worrying about a repayment crisis.

If the US debt issue does not finance government spending, why does the government issue government bonds? According to modern monetary theory, there are three reasons for this, One is to stabilize the inter-bank market interest rate. Through bond issuance, the Ministry of Finance can withdraw reserves from the banking system, thus affecting inter-bank market interest rates, At the same time, the issuance of bonds by the Ministry of Finance provides a policy tool for the central bank to conduct open market operations, thus contributing to the stability of market interest rates between existing banks. Second, as a currency issue mechanism. As mentioned above, the United States bypassed the relevant laws that prohibit the government from monetizing the fiscal deficit through "treasury bond issuance+open market operation", Therefore, treasury bond issuance, as an important part of "monetizing the fiscal deficit", provides 
issuance preparation for currency issuance. Third, maintain a stable exchange rate. Similarly to the stabilizing effect of interest rates, when US government bonds are purchased by foreign departments, it will affect the supply of US dollars in China's international money flow market, thus affecting the exchange rate of US dollars. In addition, for countries with trade surpluses that buy US Treasuries, their purchases squeeze out central government spending. China's use of foreign exchange reserves accumulated from trade surplus to purchase US Treasuries has led to the expansion of the central bank's balance sheet,In order to prevent the central bank's debt issuance caused by the expansion from being converted into basic money supply, the Ministry of Finance has to increase the fiscal surplus to hedge the excess liquidity. This would squeeze out central government spending, making it impossible for the central government to provide money adaptively to the needs of the economy. This is also the institutional root of China's long-term problems, such as weak consumption of residents, high debt of local governments and insufficient innovation of enterprises.

\section{Conclusions}

The traditional theory is based on the view of the essence of monetary goods. It holds that the issuance of U.S. bonds is to finance government expenditures. Therefore, China's purchase of U.S. government bonds from the foreign exchange income earned from the trade surplus will certainly finance U.S. government expenditures. However, the traditional theory ignores the debt attribute of money, and the modern monetary theory holds that the issuance of government bonds cannot finance government expenditures, but serves as a mechanism for adjusting interest rates, stabilizing exchange rates and issuing money. If government bonds were denominated in local currencies, there would be no solvency crisis. On the other hand, China's use of the foreign exchange accumulated in the trade surplus to purchase U.S. treasury bonds not only fails to finance U.S. government expenditures, but also weakens China's currency sovereignty while maintaining the stability of the U.S. dollar exchange rate and consolidating the hegemony of the U.S. dollar, thus deepening its dependence on the hegemony of the U.S. dollar and further inhibiting China's development in consumption of residents and innovation of enterprises. To this end, this paper has the following policy recommendations. First, the floating exchange rate system should be reformed to ensure the country's monetary sovereignty and provide sufficient policy space for China to implement active fiscal policies. Secondly, the central government should increase the issuance of national debt and strengthen the construction of national debt market. Finally, China should increase the central government expenditure, especially in education, medical care, social security, scientific and technological innovation, etc, in order to stimulate domestic demand, improve the level of domestic technological innovation, and then reduce dependence on external demand.

\section{References}

1. Mckinnon, R. (2005) Fall into the trap of international dollar standard. New Finance, 7: 3-7.

2. Dooley, M.P., Folkerts-Landau, D., Garber, P. (2004) The revived bretton woods system: the effects of periphery intervention and reserve management on interest rates \& exchange rates in center countries. NBER Working Papers, 3: 5-7.

3. Bell, S.A. (1998) Can taxes and bonds finance government spending?. Ssrn Electronic Journal, 34: 603-620.

4. Jia, G.L., Lan, W.S. (2019) The fiscal deficit view of modern monetary theory and the fallacy of western mainstream economics. Teaching and Research, 485: 77-87.

5. Huang, Y.J. (2020) Review of "Domestic Circulation: New Strategies and Policy Choices for Economic Development"-Based on the perspective of modern monetary theory. Research on financial issues, 10: 126-128.

6. Pan, H.S. (2010) Sustainability analysis of American public debt. Comparison of economic and social systems, 4: 67-72.

7. Maggiori, M., Neiman, B., Schreger, J. (2018) International currencies and capital allocation. Social Science Electronic Publishing, 12: 56-60.

8. Li, J., Yi, N. (2014) An Empirical Study on the Sustainability of American Public Debt. Journal of East China Normal University (Philosophy and Social Sciences Edition), 3: 98-106. 